\title{
Chromosome numbers and the systematics of tribe Vochysieae
} (Vochysiaceae)

\section{Júlia Yamagishi-Costa ${ }^{1}$, Andréa Rodrigues Barbosa ${ }^{2}$, Gustavo Hiroaki Shimizu² ${ }^{2 *}$ Kikyo Yamamoto ${ }^{2}$ and Eliana Regina Forni-Martins ${ }^{2}$}

Received: October 10, 2017

Accepted: January 30, 2018

\begin{abstract}
With five neotropical genera and ca. 220 species, Vochysieae is the largest tribe of Vochysiaceae, comprising more than $90 \%$ of its species. Preliminary phylogenetic analyses with matK sequence data indicated that Vochysieae may be paraphyletic, separated into the clades QRC (Qualea, Ruizterania and Callisthene) and VS (Vochysia, Salvertia). Whether the genera and the infrageneric taxa are artificial is still controversial. In this study, we analyzed the distribution of chromosome numbers in mitotic or meiotic cells among 20 species belonging to the genera Callisthene, Qualea, Salvertia, and Vochysia, that are native and common in Central and Southeast Brazilian forests or savannas. Species of Callisthene and Qualea possessed 2n = 22, while species of Salvertia and Vochysia had 2n = 24 (or $n=12$ ). These chromosome numbers corroborate the recognition of two groups, and also suggest that chromosome evolution based on numerical variation is conservative in these lineages.
\end{abstract}

Keywords: Callisthene, Cytotaxonomy, Myrtales, Neotropics, Qualea, Salvertia, Vochysia, Vochysiaceae

\section{Introduction}

Vochysiaceae is a mainly neotropical family composed of nearly 240 species (Shimizu \& Yamamoto 2012). They are trees or shrubs with simple, opposite or whorled leaves, with glandular or non-glandular stipules, zygomorphic flowers, pentamerous calyx with shallowly connate lobes in quincuncial arrangement, the fourth lobe spurred or gibbous, corolla frequently reduced to $1-3$ petals, only one fertile stamen, tiny staminodes frequently present, usually 3-carpellate and 3-loculate superior ovary with axillary ovules, and loculicidal capsules with winged seeds (Warming 1875; Stafleu 1952; Kawasaki 2007). This family was classified in Polygalales or allied suprafamilial taxa (e.g. Cronquist 1988) until phylogenetic analyses of molecular, supported by morphological, embryological and wood anatomical data, placed it within Myrtales as sister family of Myrtaceae (Conti et al. 1996; 1997; Soltis et al. 2000).

Vochysiaceae is currently composed of two tribes (Erismeae and Vochysieae) and eight genera (or seven if Ruizterania is included in Qualea), three of them (Callisthene, Qualea and Vochysia) with infrageneric divisions (Warming 1875; Stafleu 1948; 1952; 1953; Keay \& Stafleu 1953; Marcano-Berti 1969; Kawasaki 1998; 2007; Litt \& Chase 1999; Litt \& Cheek 2002; Litt \& Stevenson 2003a; b). With nearly 220 species (Callisthene - 11 spp., Qualea - ca. 50 spp., Ruizterania - 14 spp., Salvertia - 1 sp., and Vochysia ca. 140 spp.), Vochysieae is the largest tribe of the family, comprising more than $90 \%$ of the species. Litt (1999) performed phylogenetic analyses for the family, including morphological and matK sequence data, and found that

1 Botany Department, Faculty of Science, University of British Columbia, 3529-6270, University Boulevard, V6T 1Z4, Vancouver, BC, Canada
2 Departamento de Biologia Vegetal, Instituto de Biologia, Universidade Estadual de Campinas, 13083-970, Campinas, SP, Brazil

* Corresponding author: gustavoshimizu@gmail.com 


\section{Chromosome numbers and the systematics \\ of tribe Vochysieae (Vochysiaceae)}

Erismeae is a monophyletic lineage with distinct genera, while Vochysieae is uncertain. Two clades were recovered: one formed by species of Vochysia and the monospecific genus Salvertia nested among them (clade VS), and other composed of species of Qualea, Ruizterania and Callisthene (clade QRC). There is no resolution to ascertain if these two clades have a sister relationship or one of them is sister to Erismeae. This study also suggested that the generic and infrageneric divisions of Vochysieae are artificial, thus indicating the reduction to only two genera (Qualea s.l. and Vochysia s.l.). The QRC and VS clades (and the genera that compose them) have also been distinguished through peculiar combinations of flower (Litt \& Stevenson 2003a; b; Carmo-Oliveira \& Morretes 2009), fruit and seed morphological features (Stafleu 1952), together with some embryological characteristics (Boesewinkel \& Venturelli 1987). Besides, Mayworm \& Salatino (2002) found that the distribution pattern of seed fatty acid types corroborates the distinction of the clades QRC and VS, but also that this kind of data may help discriminating the two subgenera of Qualea (Q. subg. Qualea and Q. subg. Amphilochia). So, a systematic reassessment of Vochysieae is needed, especially to verify if subdivisions can be distinguished within the clades QRC and VS. In this scenario, we carried out this study to verify if chromosome data can contribute to the more comprehensive phylogenetic analysis of Vochysiaceae that G Shimizu, D Gonçalves, A Litt, K Yamamoto, and A Simões (unpubl. res.) are currently working on.

Chromosome numbers and other karyological parameters such as chromosome morphology, genome size, banding and DNA in situ hybridization patterns are of great importance, supplying characters for taxonomic studies (Stace 2000). But karyotype information on Vochysiaceae has been limited so far to chromosome numbers of only two species of one genus, Vochysia lomatophylla Standl. with 2n $=22$ (Goldblatt 1979) and $V$. venezuelana Stafleu with $2 \mathrm{n}$ $=24$ (Löve 1987). So, the aim of this article is to provide new chromosome counts for Vochysieae and to verify if and how chromosome numbers vary within and between the clades QRC and VS and among their compounding genera and subgeneric divisions. Also, considering that ploidy level variation related to habitat have been reported for other botanical families (Morawetz 1986; Félix \& Guerra 2000), we selected some species of Callisthene, Qualea and Vochysia from forest and cerrado (a Brazilian type of savanna) to analyze this feature. The results are also discussed in the context of the current knowledge about chromosome number in Myrtales.

\section{Materials and methods}

Twenty species belonging to four genera of the tribe Vochysieae (Callisthene Mart., Qualea Aubl., Salvertia A.St.-Hil. and Vochysia Aubl.) that are native and common in Central and Southeast Brazil were studied for their chromosome numbers (Tab. 1). To check for intraspecific variation, individuals of two or three populations from distinct distribution areas were studied for Qualea cordata Spreng., Vochysia cinnamomea Pohl, V. tucanorum Mart. and Salvertia convallariodora A.St.-Hil. For the other species, we examined only one population each. Vouchers of the studied specimens are held at the Herbarium of the University of Campinas (UEC). Chromosome numbers were observed in 10 or more metaphasic cells per species. Mitotic or meiotic cells were observed and photographed under Olympus BX51 microscope, using Kodak Imagelink (ISO 25) or Ilford (ISO 50) films. Because flowering and fruiting times of these species are distinct, they were collected for flower buds and/ or ripe fruits bearing mature seeds for chromosome studies. Only S. convallariodora, V. cinnamomea and V. tucanorum were studied for both mitotic and meiotic divisions. Mitotic cells were obtained from root tips of germinated seeds, pre-treated with paradichlorobenzene (PDB) saturated solution for 5 hours at $16-18{ }^{\circ} \mathrm{C}$ and fixed in 1:3 aceticalcohol (Carnoy) solution for $24 \mathrm{~h}$, and then stored in freezer $\left(-20{ }^{\circ} \mathrm{C}\right)$, preserved in $70 \%$ ethanol. The root tips were washed in distilled water, hydrolysed in $5 \mathrm{~N} \mathrm{HCl}$ for 10 min at room temperature and squashed in a drop of $45 \%$ acetic acid. After covering removal, slides were stained in $2 \%$ Giemsa solution (Guerra 1983). For the analysis of microsporogenesis, pollen mother cells were obtained from flower buds fixed in Carnoy's solution and stored in freezer, preserved in $70 \%$ ethanol; young anthers were squashed in $1.2 \%$ aceto-carmine (Medina \& Conagin 1964).

\section{Results}

Two distinct chromosome numbers were observed (Tab. 1). The number $2 n=22$ was found in two species of Callisthene (Fig. 1A-B) and four species of Qualea (Fig. 1CD), while $2 n=24$ (Fig. 1E-H) or $n=12$ (Fig. 2) were found in Salvertia convallariodora and 13 species of Vochysia. So, the basic chromosome numbers of the clades QRC and VS are respectively $\mathrm{x}=11$ and $\mathrm{x}=12$.

\section{Discussion}

The results obtained in this study corroborate the separation of the clades QRC and VS. From the two previously reported chromosome numbers for the family, $2 \mathrm{n}=24$ in V. venezuelana (Vochysia sect. Vochysiella subsect. Calophylloideae) (Löve 1987) agrees with the pattern of chromosome number we found for VS clade, but the number $2 \mathrm{n}=22$, reported for V. lomatophylla (Vochysia sect. Ciliantha subsect. Ferrugineae) by Goldblatt (1979), does not. There are no figures of the chromosomes in this latter study but it contains a description of a pair of distinctly larger chromosomes bearing satellites of similar size to other chromosomes in the karyotype. As we obtained $2 n=24$ 
Table 1. Chromosome numbers for 20 Vochysiaceae species. ARB (Andréa Rodrigues Barbosa). GO (Goiás), MG (Minas Gerais), MT (Mato Grosso) and SP (São Paulo). Habitat: Ce (Cerrado), GalF (Gallery forest), $\mathrm{MCr}$ (Mesotrophic cerradão), StmF (Subtropical high mountain forest) and TcF (Tropical coastal rain forest).

\begin{tabular}{|c|c|c|c|c|}
\hline Species & Specimen, collection site & Habitat & n & $2 n$ \\
\hline \multicolumn{5}{|l|}{ Callisthene sect. Callisthene } \\
\hline Callisthene major Mart. & ARB 213, Uberlândia (MG) & $\mathrm{Ce}$ & - & 22 \\
\hline \multicolumn{5}{|l|}{ Callisthene sect. Cataphyllantha } \\
\hline Callisthene fasciculata Mart. & ARB 209, Uberlândia (MG) & $\mathrm{MCr}$ & - & 22 \\
\hline \multicolumn{5}{|c|}{ Qualea subg. Qualea sect. Costatifolium } \\
\hline Qualea grandiflora Mart. & ARB 194, Santana do Riacho (MG) & $\mathrm{Ce}$ & - & 22 \\
\hline Qualea multiflora Mart. & ARB 215, Uberlândia (MG) & $\mathrm{Ce}$ & - & 22 \\
\hline Qualea parviflora Mart. & ARB 216, Uberlândia (MG) & $\mathrm{Ce}$ & - & 22 \\
\hline \multicolumn{5}{|l|}{ Qualea subg. Amphilochia } \\
\hline \multirow{2}{*}{ Qualea cordata Spreng. } & ARB 185, Santana do Riacho (MG) & $\mathrm{Ce}$ & - & 22 \\
\hline & ARB 201, Águas de Lindóia (SP) & $\mathrm{Ce}$ & - & 22 \\
\hline \multirow{2}{*}{ Salvertia convallariodora A.St.-Hil. } & ARB 182, Lagoa Santa (MG) & $\mathrm{Ce}$ & 12 & - \\
\hline & ARB 183, Lagoa Santa (MG) & $\mathrm{Ce}$ & - & 24 \\
\hline \multicolumn{5}{|c|}{ Vochysia sect. Ciliantha subsect. Discolores } \\
\hline Vochysia discolor Warm. & ARB 294, Gouveia (MG) & $\mathrm{Ce}$ & 12 & - \\
\hline Vochysia schwackeana Warm. & ARB 119, São José dos Campos (SP) & StmF & 12 & - \\
\hline \multicolumn{5}{|c|}{ Vochysia sect. Ciliantha subsect. Ferrugineae } \\
\hline Vochysia acuminata Bong. & ARB 250, Santana do Riacho (MG) & GalF & 12 & - \\
\hline Vochysia ferruginea Mart. & ARB 368, Nova Xavantina (MT) & GalF & 12 & - \\
\hline Vochysia selloi Warm. & ARB 229, Santo André (SP) & $\mathrm{TcF}$ & 12 & - \\
\hline \multicolumn{5}{|c|}{ Vochysia sect. Ciliantha subsect. Lutescentes } \\
\hline Vochysia bifalcata Warm. & ARB 41, Ubatuba (SP) & $\mathrm{TcF}$ & - & 24 \\
\hline \multirow{3}{*}{ Vochysia tucanorum Mart. } & ARB 15, Rio Claro (SP) & $\mathrm{Ce}$ & - & 24 \\
\hline & ARB 16, Rio Claro (SP) & $\mathrm{Ce}$ & - & 24 \\
\hline & ARB 113, Lagoa Santa (MG) & $\mathrm{Ce}$ & 12 & - \\
\hline \multicolumn{5}{|c|}{ Vochysia sect. Vochysiella subsect. Calophylloideae } \\
\hline Vochysia haenkeana Mart. & ARB 347, Caiapônia (GO) & GalF & - & 24 \\
\hline \multicolumn{5}{|c|}{ Vochysia sect. Vochysiella subsect. Decorticantes } \\
\hline \multirow{2}{*}{ Vochysia cinnamomea Pohl } & ARB 14, Itirapina (SP) & $\mathrm{Ce}$ & - & 24 \\
\hline & ARB 303, Cristalina (GO) & $\mathrm{Ce}$ & 12 & - \\
\hline Vochysia elliptica Mart. & ARB 139, Santana do Riacho (MG) & $\mathrm{Ce}$ & 12 & - \\
\hline Vochysia herbacea Pohl & ARB 338, Goiás Velho (GO) & $\mathrm{Ce}$ & 12 & - \\
\hline Vochysia pumila Pohl & ARB 336, Pirenópolis (GO) & $\mathrm{Ce}$ & - & 24 \\
\hline Vochysia rufa Mart. & ARB 208, Uberlândia (MG) & $\mathrm{Ce}$ & - & 24 \\
\hline
\end{tabular}

or $\mathrm{n}=12$ in two or more populations in all of the 13 studied species of Vochysia, we believe that $2 \mathrm{n}=22$ in $V$. lomatophylla is a miscount and that those satellites are a distinct pair of chromosomes that were partly joined to others due to technical artefact. A new count is needed to confirm the number of chromosomes in this species, but the consistency of our results indicates that chromosome number is stable within the clades QRC and VS, and then chromosome evolution regarding to numerical variation is conservative in these two lineages of Vochysieae.

All species of Qualea and Salvertia studied were collected in cerrado. On the other hand, Callisthene and Vochysia samples were obtained from different habitats (cerrado and forest physiognomies, see Tab. 1). As both genera presented constant chromosome numbers, speciation related to the occupation of those different habitats may have occurred without change in chromosome number. These results suggest that the difference from $\mathrm{x}=11$ to 12 , or vice versa, must have been a remarkable evolutionary event at the origin of the clades QRC and VS. On the other hand, the constancy of chromosome number in these clades makes this kind of evidence useless for the analysis of the generic and infrageneric divisions within the clades.

Evolutionary lineages may, or may not, be associated with variation in chromosome number. For example, Lombello \& Forni-Martins (2003) found that the two subfamilies of Malpighiaceae can be differentiated by their predominant basic chromosome numbers ( $\mathrm{x}=5$ in Malpighioideae and $\mathrm{x}=$ 6 in Byrsonimoideae) combined with fruit type and habitat. Differently, Mansanares et al. (2002; 2007a; b) found that different genera (Lychnophora, Lychnophoriopsis and Paralychnophora) of subtribe Lychnophorinae (Asteraceae) share various chromosome numbers $(2 \mathrm{n}=34,36$ and 38$)$, indicating that in this case, this feature has no discriminative value at generic level. So, stability in chromosome number may be a characteristic of lineages at different taxonomic 


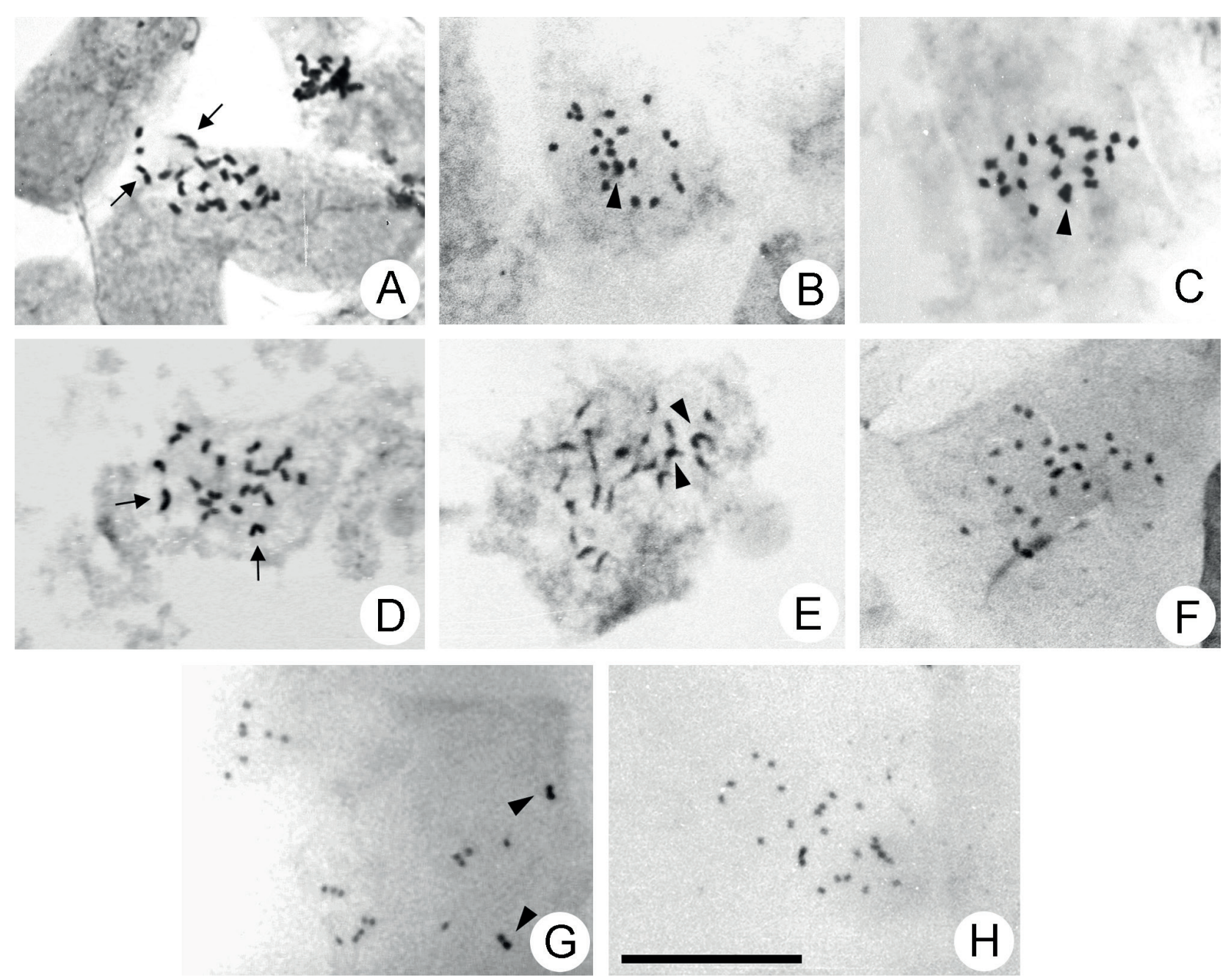

Figure 1. Mitotic metaphases of Vochysiaceae species. A-D. QRC clade, $2 \mathrm{n}=22$ chromosomes. A. Callisthene fasciculata. B. C. major. C. Qualea cordata. D. Q. parviflora. E-H. VS clade, $2 \mathrm{n}=24$ chromosomes. E. Salvertia convallariodora. F. Vochysia haenkeana. G. V. rufa. H. V. tucanorum. Scale bar $=10 \mu \mathrm{m}$. Arrowheads point to two overlapped chromosomes, arrows point to one larger chromosome.

ranks. In Myrtales, it may be found in few lineages within this order, as in the clades Onagraceae/Lythraceae and Myrtaceae/Vochysiaceae, as follows.

Myrtales encompasses nine families and about 13000 species (Stevens 2001 onwards). Combretaceae is sister to the rest of this order (Berger et al. 2016), which comprises three main branches: the Onagraceae/Lythraceae clade, the Myrtaceae/Vochysiaceae clade, and a lineage with the clades Melastomataceae and CAP (Crypteroniaceae, Alzateaceae and Penaeaceae) (APG IV 2016). Chromosome numbers have been determined for species of most of the families of Myrtales (Rice et al. 2015) and are variable among and inside them: mainly $\mathrm{n}=12$ and 13 for Combretaceae (Renard et al. 1983; Ohri 1996); $\mathrm{n}=5,6,7,8,9,10,11,14,15$ to 28, 32 for Onagraceae and Lythraceae (e.g. Raven \& Tai 1979; Tobe et al. 1986; Graham \& Cavalcanti 2001); $\mathrm{n}=$ 11 and 12 for Vochysiaceae (Goldblatt 1979; Löve 1987; this study); $\mathrm{n}=12$ for Myrtaceae-Psiloxyloideae (Wilson et al. 2005); mainly $\mathrm{n}=11$ for Myrtaceae-Myrtoideae (Rye 1979; Costa et al. 2006a; b); $n=7$ to 40 , mainly $n=17$ and
18 for Melastomataceae-Melastomoideae (Solt \& Wurdack 1980; Almeda \& Chuang 1992); $\mathrm{n}=7$ for MelastomataceaeOlisbeoideae (= Memecylaceae); $\mathrm{n}=14$ for Alzateaceae (Almeda 1997); and $\mathrm{n}=10$ to 12 for Penaeaceae (Stephens 1909; Dahlgren 1968; 1971) which also has two different records, $\mathrm{n}=10$ (Goldblatt 1976) and $\mathrm{n}=12$ (Takhtajan 1997), for Olinia (Oliniaceae, now included in Penaeaceae).

Considering that variation in chromosome number in Myrtaceae is not frequent (see Rye 1979; Costa \& ForniMartins 2006a; b; 2007; Costa et al. 2008), stability in chromosome number seems to be characteristic of the clade Myrtaceae/Vochysiaceae. In this clade, it is particularly noticeable that the basic chromosome numbers $\mathrm{x}=11$ and $\mathrm{x}$ = 12 separate the two subfamilies of Myrtaceae (Myrtoideae and Psiloxyloideae), as well as the clades QRC and VS in Vochysieae. Another feature shared by the members of this clade is the small size of the chromosomes. Costa \& ForniMartins (2007) have found very small chromosomes (<2.0 $\mu \mathrm{m})$ in Myrtaceae, and we can see in Fig. 1 that Vochysiaceae also present small chromosomes (ca. $1.0 \mu \mathrm{m}$ ). This may be 

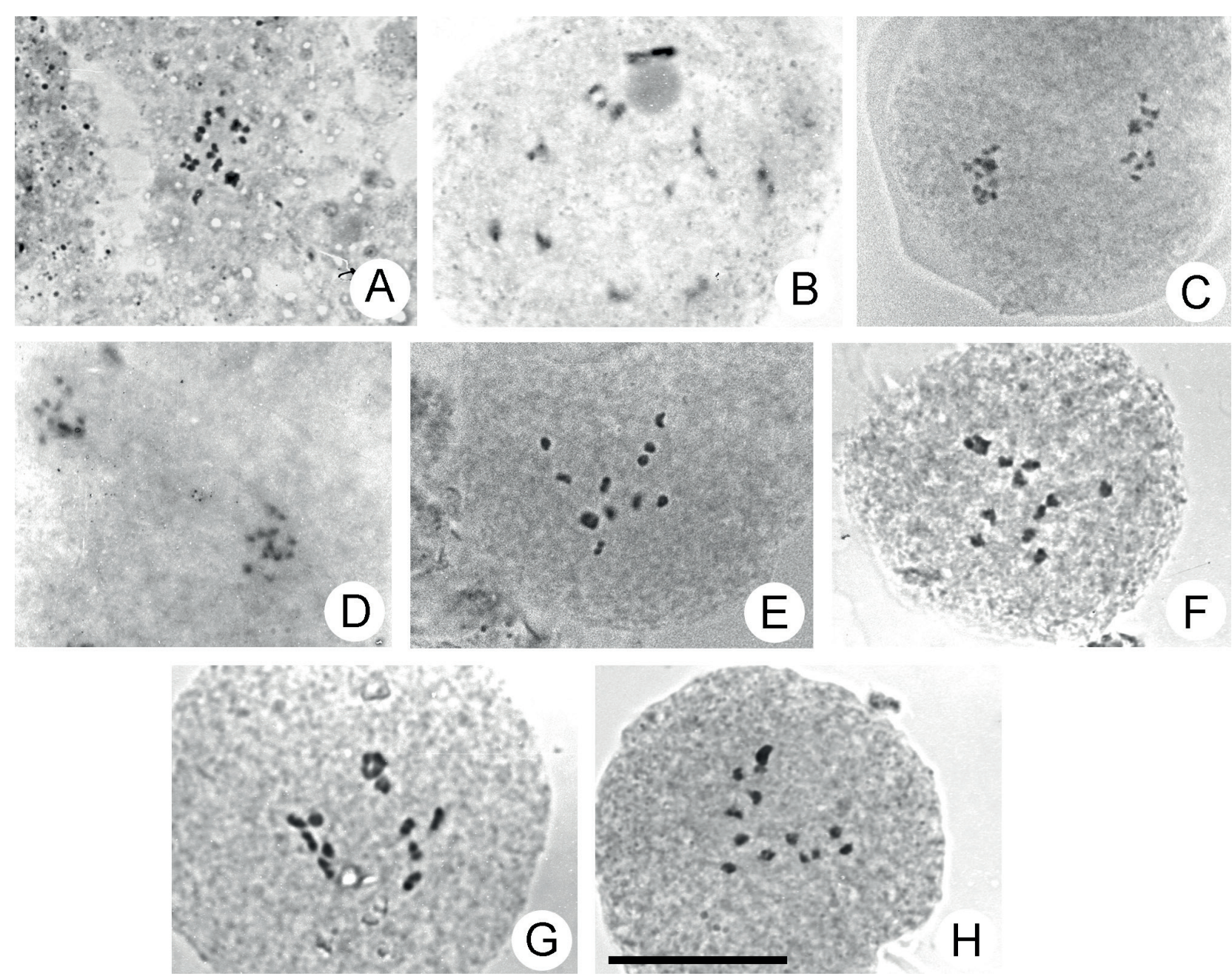

Figure 2. Meiotic cells of Vochysiaceae species from VS clade, with $\mathrm{n}=12$ bivalents. A. Salvertia convallariodora (metaphase I). B. Vochysia elliptica (diakinesis). C. V. herbacea (metaphase II). D. V. discolor (anaphase II). E. V. schwackeana (metaphase I). F. V. acuminata (metaphase I). G. V. ferruginea (metaphase I). H. V. selloi (metaphase I). Scale bar $=10 \mu \mathrm{m}$.

a common feature in Myrtales since it has also been found in other families of this order, like Lythraceae $(0.5-4.0 \mu \mathrm{m})$ (Tjio 1948; Graham 2007) and Melastomataceae (0.5-3.0 $\mu \mathrm{m})$ (Solt \& Wurdack 1980; Almeda \& Chuang 1992).

Evolution based on variation in chromosome number seems to have occurred in different ways in the two larger families of Myrtales, Melastomataceae (ca. 170 genera and 5400 species) (Goldenberg et al. 2015) and Myrtaceae (ca. 142 genera and 5500 species) (Wilson 2011). The basic chromosome number in Melastomataceae varies considerably, especially in subfamily Melastomoideae, which most frequent haploid numbers have been reported to be $\mathrm{n}=9,12$ or 17 (Solt \& Wurdack 1980), while $\mathrm{n}=11$ is very frequent and widespread among different groups of Myrtaceae. Sytsma et al. (2004) found that the rates of sequence evolution were accelerated and seemingly related to morphological and ecological diversification and changes in chromosome number in Melastomataceae, a family that comprises woody, herbaceous and even epiphytic species, from forests or savannas but sometimes from wet areas such as lakes or stream shores as well (Renner 1993). Otherwise, rates of sequence evolution were found to be slow in Myrtaceae (Sytsma et al. 2004), a family comprised only of trees or shrubby species from forests and savannas.

In Myrtaceae, the sister family of Vochysiaceae, polyploidy and disploidy are common chromosome evolutionary events, the first one being mostly limited to the fleshy-fruited Myrtoideae (McVaugh 1968; Costa \& Forni-Martins 2006a; b) and the latter one being more common in some dryfruited genera (Rye 1979) like Eucalyptus (Matsumoto et al. 2000). Vochysiaceae, or at least the two clades comprised in its larger tribe Vochysieae, seems to follow a similar pattern to Myrtaceae, comprising only trees or shrubs in forests or savannas and with stability in chromosome number but, so far, with no records of polyploidy. The pattern of occurrence of two basic chromosome numbers ( $\mathrm{x}=11$ or 12) in Vochysieae suggests that one event of disploidy or aneuploidy occurred early in the evolution of this group. Although the sister relationships between Erismeae, QRC and VS clades are still uncertain (Litt 1999), in a scenario 


\section{Chromosome numbers and the systematics \\ of tribe Vochysieae (Vochysiaceae)}

where Vochysieae is monophyletic (Sytsma et al. 2004), the change in the basic chromosome number must have contributed to the subsequent separation of the clades VS and QRC.

Further studies to verify the chromosome number in more species of Vochysiaceae are desirable, especially including Amazonian and Andean species of Vochysieae and American and African members of Erismeae. Knowing the basic chromosome number of Erismeae will add more evidences to infer the relationships among the members of the family, as well as help to unravel some aspects of the chromosome evolution in the Myrtaceae/Vochysiaceae clade.

\section{Acknowledgements}

This paper is part of the results of $\mathrm{PhD}$ dissertation studies of the second author, with cooperation of J. Yamagishi-Costa, when they were both students of the "Curso de Pós-Graduação em Biologia Vegetal" of the University of Campinas, SP, Brazil. We thank CAPES for field work resources and a scholarship to A.R. Barbosa, and $\mathrm{CNPq}$ for a grant to E.R. Forni-Martins. We also thank the reviewers for their contribution.

\section{References}

Almeda F. 1997. Chromosomal observations on the Alzateaceae (Myrtales). Annals of the Missouri Botanical Garden 84: 305-308.

Almeda F, Chuang TI. 1992. Chromosome numbers and their systematic significance in some Mexican Melastomataceae. Systematic Botany 17: 583-593.

APG - Angiosperm Phylogeny Group IV. 2016. An update of the Angiosperm Phylogeny Group classification for the orders and families of flowering plants: APG IV. Botanical Journal of the Linnean Society 181: 1-20.

Berger BA, Kriebel R, Spalink D, Sytsma KJ. 2016. Divergence times, historical biogeography and shifts in speciation rates of Myrtales. Molecular Phylogenetics and Evolution 95: 116-136.

Boesewinkel FD, Venturelli M. 1987. Ovule and seed structure in Vochysiaceae. Botanische Jahrbücher für Systematik, Pflanzengeschichte und Pflanzengeographie 108: 547-566.

Carmo-Oliveira R, Morretes BL. 2009. Stigmatic surface in the Vochysiaceae: reproductive and taxonomic implications. Acta Botanica Brasilica 23: 780-785.

Conti E, Litt A, Sytsma KJ. 1996. Circumscription of Myrtales and their relationships to other rosids: evidence from $r b c L$ sequence data. American Journal of Botany 83: 221-233.

Conti E, Litt A, Wilson PG, et al. 1997. Interfamilial relationships in Myrtales: molecular phylogeny and patterns of morphological evolution. Systematic Botany 22: 629-647.

Costa IR, Dornelas MC, Forni-Martins ER. 2008. Evolution of nuclear DNA content among neotropical Myrtaceae (fleshy-fruited Myrtaceae). Plant Systematics and Evolution 276: 209-217.

Costa IR, Forni-Martins ER. 2006a. Chromosome studies in species of Eugenia, Myrciaria and Plinia (Myrtaceae) from south-eastern Brazil. Australian Journal of Botany 54: 409-415.

Costa IR, Forni-Martins ER. 2006b. Chromosomal studies in species of Campomanesia Ruiz \& Pávon and Psidium L. (Myrtaceae) in the southeastern of Brazil. Caryologia 59: 7-13.

Costa IR, Forni-Martins ER. 2007. Chromosomal studies in Gomidesia, Marlierea, Myrceugenia and Myrcia (Myrtaceae, subtribe Myrciinae). Kew Bulletin 62: 113-118.
Cronquist A. 1988. The evolution and classification of flowering plants. 2nd. edn. New York, The New York Botanical Garden.

Dahlgren R. 1968. Studies on Penaeaceae. Part II. The genera Brachysiphon, Sonderothamnus and Saltera. Opera Botanica 18: 1-72.

Dahlgren R. 1971. Studies on Penaeaceae. VI. The genus Penaea L. Opera Botanica 29: 5-58.

Félix LP, Guerra M. 2000. Cytogenetic and cytotaxonomy of some Brazilian species of Cymbidioid orchids. Genetics and Molecular Biology 23: 957-978.

Goldblatt P. 1976. New or noteworthy chromosome records in the angiosperms. Annals of the Missouri Botanical Garden 63: 889-895.

Goldblatt P. 1979. Miscellaneous chromosome counts in angiosperms II, including new family and generic records. Annals of the Missouri Botanical Garden 66: 856-861.

Goldenberg R, Almeda F, Sosa K, Ribeiro RC, Michelangeli FA. 2015. Rupestrea: a new Brazilian genus of Melastomataceae, with anomalous seeds and dry indehiscent fruits. Systematic Botany 40: 561-571.

Graham SA. 2007. Lythraceae. In: Kubitzki K. (ed.) The families and genera of vascular plants. Vol. IX. Berlin, Heidelberg, Springer Verlag. p. 226-246.

Graham SA, Cavalcanti TB. 2001. New chromosome counts in the Lythraceae and a review of chromosome numbers in the family. Systematic Botany 26: 445-458.

Guerra M. 1983. O uso de Giemsa em citogenética vegetal: comparação entre a coloração simples e o bandeamento. Ciência e Cultura 35: 190-193.

Kawasaki ML. 1998. Systematics of Erisma (Vochysiaceae). Memoirs of the New York Botanical Garden 81: 1-40.

Kawasaki ML. 2007. Vochysiaceae. In: Kubitzki K. (ed.) The families and genera of vascular plants. Vol. IX. Berlin, Springer. p. 480-487.

Keay RWJ, Stafleu FA. 1953. Erismadelphus. Acta Botanica Neerlandica 1: 594-599.

Litt A. 1999. Floral morphology and phylogeny of Vochysiaceae. PhD Thesis, The City University of New York, New York.

Litt A, Chase MW. 1999. The systematic position of Euphronia, with comments on the position of Balanops: an analysis based on $r b c L$ sequence data. Systematic Botany 23: 401-409.

Litt A, Cheek M. 2002. Korupodendron songweanum, a new genus and species of Vochysiaceae from West-Central Africa. Brittonia 54: 13-17.

Litt A, Stevenson DW. 2003a. Floral development and morphology of Vochysiaceae. I. The structure of the gynoecium. American Journal of Botany 90: 1533-1547.

Litt A, Stevenson DW. 2003b. Floral development and morphology of Vochysiaceae. II. The position of the single fertile stamen. American Journal of Botany 90: 1548-1559.

Lombello RA, Forni-Martins ER. 2003. Malpighiaceae: correlations between habit, fruit type and basic chromosome number. Acta Botanica Brasilica 17: 171-178.

Löve A. 1987. Chromosome number reports XCV. Taxon 36: 493-498.

Mansanares ME, Forni-Martins ER, Semir J. 2002. Chromosome numbers in the genus Lychnophora Mart. (Lychnophorinae, Vernonieae, Asteraceae). Caryologia 55: 367-374.

Mansanares ME, Forni-Martins ER, Semir J. 2007a. Cytotaxonomy of Lychnophora Mart. (Asteraceae: Vernonieae: Lychnophorinae) species. Caryologia 60: 21-28.

Mansanares ME, Forni-Martins ER, Semir J. 2007b. Cytotaxonomy of Lychnophoriopsis Sch.Bip. and Paralychnophora MacLeish species (Asteraceae: Vernonieae: Lychnophorinae). Botanical Journal of the Linnean Society 154: 109-114.

Marcano-Berti L. 1969. Un nuevo género de las Vochysiaceae. Pittieria 2: 3-27.

Matsumoto ST, Marin-Morales MA, Ruas CF, Ruas PM. 2000. Cytogenetic analysis of seven species of Eucalyptus L'Hér. (Myrtaceae). Caryologia 53: 205-212.

Mayworm MAS, Salatino A. 2002. Distribution of seed fatty acids and the taxonomy of Vochysiaceae. Biochemical Systematics and Ecology 30: 961-972.

McVaugh R. 1968. The genera of American Myrtaceae - an interim report. Taxon 17: 354-418. 


\section{Júlia Yamagishi-Costa, Andréa Rodrigues Barbosa, Gustavo Hiroaki Shimizu, Kikyo Yamamoto and Eliana Regina Forni-Martins}

Medina DM, Conagin CHTM. 1964. Técnica citológica. Publicação 2610. Campinas, Instituto Agronômico.

Morawetz W. 1986. Remarks on karyological differentiation patterns in tropical woody plants. Plant Systematics and Evolution 152: 49-100.

Ohri D. 1996. Genome size and polyploidy variation in the tropical hardwood genus Terminalia (Combretaceae). Plant Systematics and Evolution 200: 225-232.

Raven PH, Tai W. 1979. Observations of chromosomes in Ludwigia (Onagraceae). Annals of the Missouri Botanical Garden 66: 862-879.

Renard R, Lambinon J, Reekmans M, Veken P, Govaert M. 1983. Nombres chromosomiques des quelques Angiospermes du Rwanda, du Burundi et du Kenya. Bulletin du Jardin Botanique National de Belgique 53: 343-371.

Renner SS. 1993. Phylogeny and classification of the Melastomataceae and Memecylaceae. Nordic Journal of Botany 13: 519-540.

Rice A, Glick L, Abadi S, et al. 2015. The Chromosome Counts Database (CCDB) - a community resource of plant chromosome numbers. New Phytologist 206: 19-26.

Rye BL. 1979. Chromosome number variation in the Myrtaceae and its taxonomic implications. Australian Journal of Botany 27: 547-573.

Shimizu GH, Yamamoto K. 2012. Vochysiaceae. In: Jacobi CM, Carmo FF. (eds.) Diversidade florística nas Cangas do Quadrilátero Ferrífero. Belo Horizonte, Código Editora. p. 209-210.

Solt ML, Wurdack JJ. 1980. Chromosome numbers in the Melastomataceae. Phytologia 47: 199-220.

Soltis DE, Soltis PS, Chase MW, et al. 2000. Angiosperm phylogeny inferred from $18 \mathrm{~S}$ rDNA, $r b c L$, and $a t p B$ sequences. Botanical Journal of the Linnean Society 133: 381-461.

Stace CA. 2000. Cytology and cytogenetics as a fundamental taxonomic resource for the $20^{\text {th }}$ and $21^{\text {st }}$ centuries. Taxon 49: 451-477.
Stafleu FA. 1948. A monograph of the Vochysiaceae I. Salvertia and Vochysia. Recueil des Travaux Botaniques Néerlandais 41: 397-540.

Stafleu FA. 1952. A monograph of the Vochysiaceae II. Callisthene. Acta Botanica Neerlandica 1: 222-242.

Stafleu FA. 1953. A monograph of the Vochysiaceae III. Qualea. Acta Botanica Neerlandica 2: 144-217.

Stephens EL. 1909. The embryo-sac and embryo of certain Penaeaceae. Annals of Botany 23: 363-378.

Stevens PF. 2001 onwards. Angiosperm Phylogeny Website. Version 14. July 2017. http://www.mobot.org/MOBOT/research/APweb/. 18 Sept. 2017.

Sytsma KJ, Litt A, Zjhra ML, et al. 2004. Clades, clocks, and continents: historical and biogeographical analysis of Myrtaceae, Vochysiaceae, and relatives in the southern hemisphere. International Journal of Plant Sciences 165: S85-S105.

Takhtajan A. 1997. Diversity and classification of flowering plants. New York, Columbia University Press.

Tjio JH. 1948. The somatic chromosomes of some tropical plants. Hereditas 34: $135-146$

Tobe H, Raven PH, Graham SA. 1986. Chromosome counts for some Lythraceae sens. str. (Myrtales), and the base number of the family. Taxon 35: 13-20.

Warming E. 1875. Vochysiaceae. In: Martius CFP, Eichler AW. (eds.) Flora Brasiliensis. Vol. XIII. Leipzig, Frid. Fleischer. p. 17-116.

Wilson PG. 2011. Myrtaceae. In: Kubitzki K. (ed.) The families and genera of vascular plants. Vol. X. Berlin, Heidelberg, Springer Verlag. p. 212-271.

Wilson PG, O'Brien MM, Heslewood MM, Quinn CJ. 2005. Relationships within Myrtaceae sensu lato based on a matK phylogeny. Plant Systematics and Evolution 251: 3-19. 